\title{
Studies in Somatic Growth, Biological Maturation, Physical Fitness and Activity in Portuguese Speaking Countries: an Overview
}

\author{
DL Freitas \\ University of Madeira \\ Department of Physical Education and Sports \\ JA Maia, AT Marques \\ University of Oporto \\ Faculty of Sports Sciences and Physical Education
}

\author{
GP Beunen, JA Lefevre, AL Claessens, MA Thomis \\ Katholieke Universiteit Leuven \\ Faculty of Physical Education and Physiotherapy \\ Department of Sport and Movement Sciences \\ RM Philippaerts \\ Ghent University, Faculty of Medicine and Health Sciences, \\ Department of Movement and Sports Sciences.
}

\section{RESUMO}

Estudos sobre crescimento somático, maturação biológica, aptidão física e actividade física nos países de língua oficial portuguesa: uma revisão

O presente estudo tem como objectivos: (1) situar os trabalhos efectuados na Comunidade dos Países de Língua Portuguesa e (2) apresentar algumas recomendações para investigações futuras. Dezassete estudos são considerados e extraídas as seguintes conclusões: (1) a quase totalidade dos estudos apresentam um delineamento transversal; (2) no contexto da Comunidade dos Países de Língua Portuguesa, a altura e peso das crianças Portuguesas e Brasileiras são quase idênticos, enquanto os jovens de Moçambique são mais baixos e mais leves. As crianças de Cabo Verde e Moçambique apresentam menos gordura subcutânea do que as crianças Portuguesas e Brasileiras. No teste 'sit and reach' os Moçambicanos apresentam os melhores resultados mas o oposto é verdadeiro para o 'sit ups'. Na corrida/andar de 12 minutos os Portugueses apresentam melhores resultados do que os Brasileiros; (3) no contexto Europeu, os rapazes e raparigas Brasileiros e Moçambicanos são ligeiramente mais baixos do que os Belgas. As crianças e adolescentes de Moçambique são mais leves e têm níveis de gordura subcutânea mais baixos do que os Belgas. No 'sit and reach' os rapazes e raparigas Moçambicanos apresentam melhores resultados do que os seus pares Belgas. Estudos de crescimento futuros devem privilegiar: (1) delineamentos longitudinais ou longitudinais mistos; (2) equipas de investigação multidisciplinares; (3) metodologias de treino da equipa de campo bem definidas; (4) controlo rigoroso na recolha e entrada dos dados no computador; e (5) parâmetros relacionados com a saúde.

Palavras-chave: CPLP, crescimento, maturação, aptidão física e actividade física. 


\section{INTRODUCTION}

In 1989, at the time of the 1st Congress on Physical Education and Sports Sciences of the Portuguese Speaking Countries, a number of studies and projects on growth, maturation, physical fitness and activity were presented. These studies were conducted over the past years in Portuguese Speaking Countries (CPLP). The main purpose of those studies was to construct their own reference values for growth, maturation and physical fitness.

Simultaneously, other characteristics such as regular physical activity, physiological parameters and socioeconomic status were also considered with the purpose of better understanding human variability and provide more evidence for the associations between physical fitness and health.

Although the Portuguese language is not directly implicated in these processes, genetic and cultural aspects can be on the basis of some morphological and functional similarity. The colonisation by the Portuguese and the departure of African slaves to Brazil justify the existence of common trends. However, distinct socio-economic realities are found in these countries.

With the exception of Portugal, the countries that integrate the CPLP are classified by the World Bank as Developing Countries. African countries (Angola, Cabo Verde, Guiné-Bissau, Mozambique and São Tomé and Príncipe) are considered very poor. Infantile mortality and illiteracy rates and Gross Domestic Product show values that go negatively away from the world average. Brazil is better positioned in socio-economic terms but reveals a lot of disequilibrium in wealth distribution. The adverse climatic conditions (flood and drying periods) and the civil wars experienced in Angola and Mozambique also guide to a lack of food with straight repercussions in growth and maturation processes.

During the last years attempts to review the studies made in CPLP were not carried on. Knowledge about study designs and main results of the researches will constitute important pieces in the development of the future actions. Methodological changes, inclusion of other variables and the beginning of common projects are the main implications of this paper. In this context, the present review has the following purposes: (1) to summarize the findings of the studies made in the CPLP between 1989 and 1999; and (2) to present recommendations to be considered in future research.

\section{METHODOLOGY}

The reviewed studies are included in three large groups: Portugal, Brazil and African countries. Home country, research in growth, maturation, fitness and physical activity, experimental nature, age-groups (first two decades of life), accessibility to the reader and the period of realization of the studies (till 1999) are the selection criteria used. For a better facility of exposition, the studies were examined in terms of sample, study design, components and main results.

Height, weight, sum of skinfolds (triceps and subscapular), sit and reach, sit ups and 12-minute run/walk were compared among CPLP countries and with Belgian $(27 ; 30 ; 18)$ and Netherlands $(16 ; 17)$ groups.

\section{STUDIES EXECUTED IN CPLP}

Tables 1-3 present the most important characteristics of the studies conducted in CPLP. A total of seventeen studies, eight of which took place in Portugal, seven in Brazill ${ }^{1}$, one in Mozambique and another in Cabo Verde within the period of 1972 and 1999 are considered. From the seventeen studies only eleven were published, five in books and six as papers.

The samples comprised children and youth of both sexes from 7 to 18 years. Apart from that, and with exception of the preliminary presentation of the mixed-longitudinal study in progress in the Autonomous Region of Madeira (9) and the longitudinal studies of Nahas et al. (23) and Duarte (8) in Brazil, the totality of the studies is of a cross-sectional nature.

With regard to anthropometry, body mass, height and skinfolds are included in about $2 / 3$ of the studies. The bone diameters and muscular circumferences are also measured in the studies of Sobral (31; 32), Sobral and Marques (33), Duarte (8), Matsudo (22), Madureira (20), Freitas et al. (10) and Lopes (19). For maturational status, the inspection of the secondary sex characteristics (pubic hair) and determination of age at menarche were used most often. The study of Freitas et al. (10) combines the retrospective and status quo methods for age at menarche with the skeletal maturation assessed from a xray to the left hand and wrist.

\footnotetext{
${ }^{1}$ The study made by Madureira (20) includes samples from Portugal and Brazil. For this revision it is considered as a Brazilian study.
} 
Table 1. Studies made in the Community of Portuguese Speaking Countries: Portugal

\begin{tabular}{|c|c|c|c|c|}
\hline Authors/Country & Subjects & Design & Title, test programs and components & Main results \\
\hline Brito (?) & $\begin{array}{l}\text { - Females } \\
\text { (the sample } \\
\text { is not } \\
\text { precise) } \\
\text { - Ages of } 11 \text {, } \\
13 \text { and } 15 \\
\text { years. }\end{array}$ & $\begin{array}{l}\text { - Cross- } \\
\text { sectional }\end{array}$ & $\begin{array}{l}\text { - Sounding on the physical condition } \\
\text { (performance) of the Portuguese } \\
\text { female school population of } 11,13 \\
\text { and } 15 \text { years of age. } \\
\text { - Adaptation of AAHPER [2] } \\
\text { - Motor } \\
\text { - Muscular strength and endurance } \\
\text { (abdominal and upper body) } \\
\text { - Anaerobic power } \\
\text { - Speed } \\
\text { - Agility }\end{array}$ & $\begin{array}{l}\text { - Presentation of the results in } \\
\text { percentile tables by factor and } \\
\text { age, without any analysis and } \\
\text { discussion of the same. }\end{array}$ \\
\hline Nunes et al. (25) & $\begin{array}{l}\text { - } 6078 \text { (no } \\
\text { distinction } \\
\text { between } \\
\text { sexes] } \\
\text { - Ages } \\
\text { between } 13 \\
\text { and } 17 \\
\text { years. }\end{array}$ & $\begin{array}{l}\text { - Cross- } \\
\text { sectional }\end{array}$ & $\begin{array}{l}\text { - Characterisation of the school } \\
\text { teenager - assessment of the } \\
\text { physical condition } \\
\text { - Initial outline of the Eurofit (1) } \\
\text { - Motor } \\
\text { - Cardiorespiratory endurance } \\
\text { - Flexibilility } \\
\text { - Strength } \\
\text { - Upper body (static and dynamic) } \\
\text { - Abdominal } \\
\text { - Inferior } \\
\text { - Agility } \\
\text { - Speed }\end{array}$ & $\begin{array}{l}\text { - The boys presented better results } \\
\text { than girls in all tests and ages, } \\
\text { with the exception of flexibility. }\end{array}$ \\
\hline Sobral $(31 ; 32)$ & $\begin{array}{l}1008 \text { [ } 531 \\
\text { boys and } \\
477 \text { girls] } \\
\text { - Ages } \\
\text { between } 13 \\
\text { and } 17 \\
\text { years. }\end{array}$ & $\begin{array}{l}\text { - Cross- } \\
\text { sectional }\end{array}$ & $\begin{array}{l}\text { - Statistic and anthropometric and } \\
\text { normatives physical values of the } \\
\text { Autonomous Region of Azores/Growth } \\
\text { state and physical fitness of the } \\
\text { school population of Azores. } \\
\text { - Set of tests selected according to } \\
\text { criteria established by the author. } \\
\text { - Motor } \\
\text { - Cardiorespiratory endurance } \\
\text { - Strength } \\
\text { - Upper body (static and dynamic] } \\
\text { - Abdominal } \\
\text { - Inferior } \\
\text { - Speed } \\
\text { - Somatic } \\
\text { - Weight } \\
\text { - Height } \\
\text { - Skinfolds } \\
\text { - Diameters } \\
\text { - Circumferences }\end{array}$ & $\begin{array}{l}\text { - The boys and girls of Azores } \\
\text { present in the explosive strength } \\
\text { tests of upper body higher } \\
\text { performances than those of } \\
\text { Belgian youth. } \\
\text { - Azorians of both sexes present } \\
\text { similar performances to the } \\
\text { Spanish in sit ups. } \\
\text { - The Azorians present inferior } \\
\text { values in weight and height } \\
\text { relatively to the Portuguese } \\
\text { mainland population. } \\
\text { - In skinfolds and in both sexes, the } \\
\text { values of Azorians are higher than } \\
\text { those of English and Italian. } \\
\text { - The girls present in subscapular } \\
\text { and triceps skinfolds higher values } \\
\text { than the boys. } \\
\text { amounts of the three skinfolds of }\end{array}$ \\
\hline
\end{tabular}


- Head dimensions

the Azores sample are higher than the registered of the European population used in the discussion.

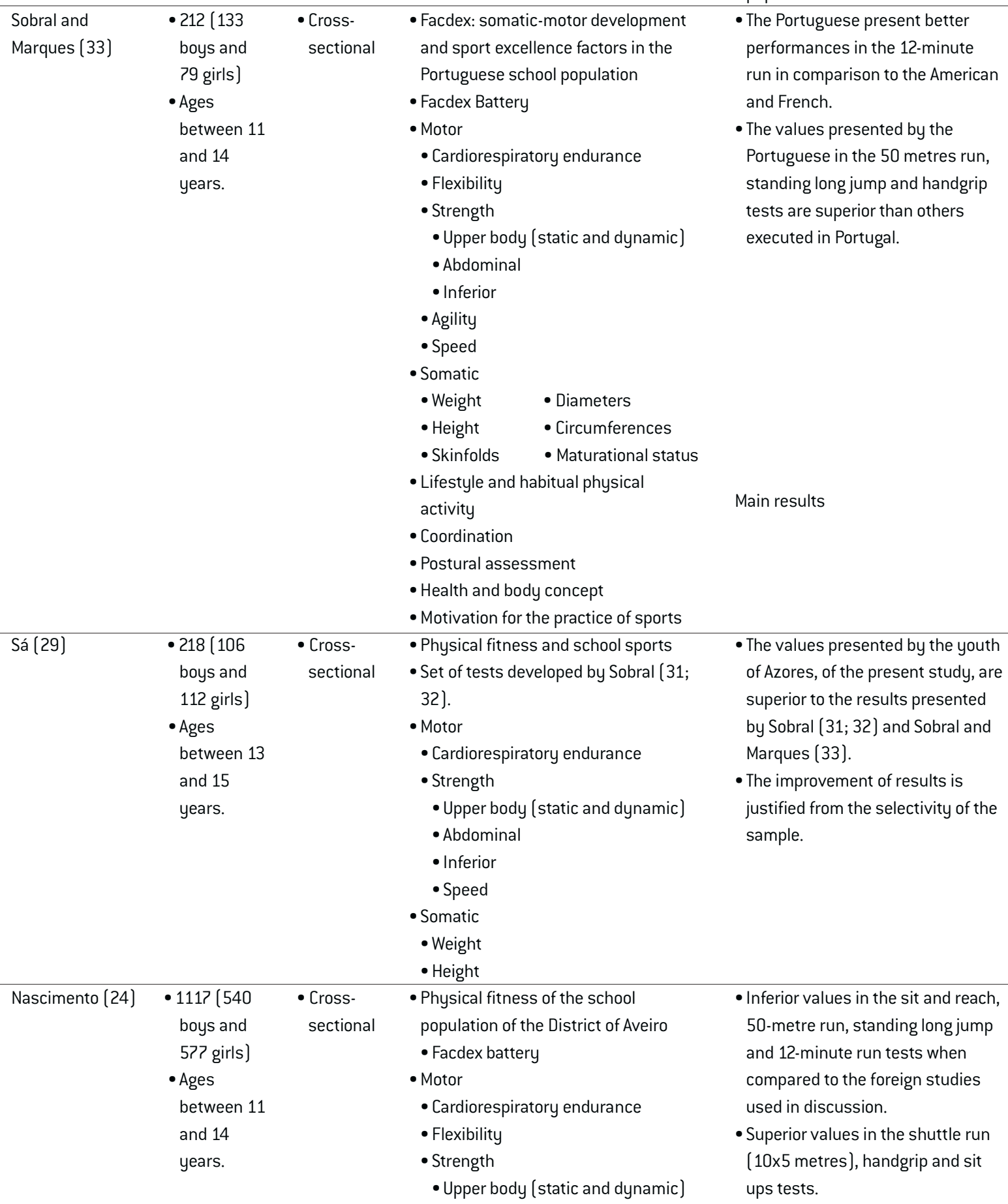




\begin{tabular}{|c|c|c|c|c|}
\hline & & & $\begin{array}{l}\text { - Abdominal } \\
\text { - Inferior } \\
\text { - Agility } \\
\text { - Speed }\end{array}$ & \\
\hline $\begin{array}{l}\text { Freitas et al. } \\
\text { (11) }\end{array}$ & $\begin{array}{l}-583 \text { ( } 253 \\
\text { boys and } \\
330 \text { girls] } \\
\text { - Ages } \\
\text { between } 11 \\
\text { and } 15 \\
\text { years. }\end{array}$ & $\begin{array}{l}\text { - Cross- } \\
\text { sectional }\end{array}$ & $\begin{array}{l}\text { - Physical fitness of the school } \\
\text { population of the Autonomous Region } \\
\text { of Madeira } \\
\text { - Facdex battery } \\
\text { - Motor } \\
\text { - Cardiorespiratory endurance } \\
\text { - Flexibility } \\
\text { - Strength } \\
\text { - Upper body (static and dynamic) } \\
\text { - Abdominal } \\
\text { - Inferior } \\
\text { - Agility } \\
\text { - Speed }\end{array}$ & $\begin{array}{l}\text { - General tendency for inferior } \\
\text { results compared to the remaining } \\
\text { reference populations in the sit } \\
\text { and reach and standing long jump } \\
\text { tests. } \\
\text { - Similar values to the remaining } \\
\text { populations in the sit ups and } \\
\text { handgrip tests. }\end{array}$ \\
\hline $\begin{array}{l}\text { Freitas et al. } \\
\text { (10) }\end{array}$ & $\begin{array}{l}\bullet 507 \text { ( } 256 \\
\text { boys and } \\
251 \text { girls] } \\
\text { - Ages } \\
\text { between } 8 \\
\text { and } 18 \\
\text { years. }\end{array}$ & $\begin{array}{l}\text { Mixed- } \\
\text { longitudi } \\
\text { nal }\end{array}$ & $\begin{array}{l}\text { - Madeira Growth Study } \\
\text { - Eurofit battery/AAHPERD (3) } \\
\text { - Motor } \\
\text { - Cardiorespiratory endurance } \\
\text { - Flexibility } \\
\text { - Strength } \\
\text { - Upper body (static) } \\
\text { - Abdominal } \\
\text { - Inferior } \\
\text { - Agility } \\
\text { - Speed (of the limbs) } \\
\text { - Balance } \\
\text { - Somatic } \\
\text { - Weight - Circumferences } \\
\text { - Height } \\
\text { - Skinfolds } \\
\text { - Diameters } \\
\text { - Maturational status } \\
\text { - Physical activity } \\
\text { - Socio-economic }\end{array}$ & • The results were not published. \\
\hline
\end{tabular}


Table 2. Studies made in the Community of Portuguese Speaking Countries: Brazil

\begin{tabular}{|c|c|c|c|c|}
\hline Authors/Country & Subjects & Design & $\begin{array}{l}\text { Title, test programs and } \\
\text { components }\end{array}$ & Main results \\
\hline Nahas et al. (23) & $\begin{array}{l}-84 \text { ( } 40 \\
\text { boys and } \\
44 \text { girls) } \\
\text { - Ages } \\
\text { between } \\
7 \text { and } 10 \\
\text { years. }\end{array}$ & & $\begin{array}{l}\text { - Growth and health-related } \\
\text { fitness in children from } 7 \text { to } 10 \\
\text { years old - a longitudinal } \\
\text { study. } \\
\text { - Adaptation of AAHPERD (3) } \\
\text { - Motor } \\
\text { - Cardiorespiratory endurance } \\
\text { - Flexibility } \\
\text { - Strength } \\
\text { - Upper body } \\
\text { - Abdominal } \\
\text { - Somatic } \\
\text { - Weight } \\
\text { - Height } \\
\text { - Sitting height } \\
\text { - Skinfolds }\end{array}$ & $\begin{array}{l}\text { - Growth data are inside of normal } \\
\text { patterns when compared with } \\
\text { international references. In Brazil } \\
\text { context, data for boys and girls from } \\
\text { Florianopolis are superior than other } \\
\text { Regions. } \\
\text { - Boys present in somatic and motor } \\
\text { variables better results than girls. For } \\
\text { sit and reach the opposite is found. }\end{array}$ \\
\hline Duarte (8) & $\begin{array}{l}-44 \text { ( } 26 \\
\text { boys and } \\
18 \text { girls) } \\
\text { - Ages } \\
\text { between } \\
7 \text { and } 18 \\
\text { years. }\end{array}$ & - Longitudinal & $\begin{array}{l}\text { - Longitudinal study of pubertal } \\
\text { peak height velocity and } \\
\text { related morphological and } \\
\text { functional components in } \\
\text { Brazilian children. } \\
\text { - Set of tests selected according } \\
\text { to criteria established by the } \\
\text { author. } \\
\text { - Motor } \\
\text { - Strength } \\
\text { - Upper body } \\
\text { - Inferior } \\
\text { - Speed } \\
\text { - Agility } \\
\text { - Somatic } \\
\text { - Weight } \\
\text { - Height } \\
\text { - Skinfolds } \\
\text { - Diameters } \\
\text { - Circumferences } \\
\text { - Maturational status }\end{array}$ & $\begin{array}{l}\text { - The mean age of Peak Height Velocity } \\
\text { (PHV) in llhabela girls and boys was } \\
11.55 \pm 1.11 \text { and } 13.99 \text { years, } \\
\text { respectively). The magnitude of PHV } \\
\text { was } 9.15 \mathrm{~cm} \text { /year for girls and } 9.72 \\
\mathrm{~cm} / \text { year for boys. } \\
\text { - The mean age of menarche for llhabela } \\
\text { girls was } 12.67 \text { years. } \\
\text { - A growth spurt was observed in the } \\
\text { female group in body weight, sum of } 7 \\
\text { skinfolds, handgrip and shuttle run } \\
\text { performance. Growth spurts were also } \\
\text { observed in weight, vertical jump, } \\
\text { standing broad jump, hand grip } \\
\text { strength, and } 50 \mathrm{~m} \text { run in llhabela boys. } \\
\text {-A peak velocity coincident with or } \\
\text { close to PHV was observed in Ilhabela } \\
\text { girls for sum of } 7 \text { skinfolds, handgrip, } \\
\text { and shuttle run, while for boys a peak } \\
\text { velocity was demo nstrated for body } \\
\text { weight, vertical jump, standing broad } \\
\text { jump, handgrip, and } 50 \mathrm{~m} \text { run. } \\
\text { - The developmental curves of girls and } \\
\text { boys from Ilhabela when analyzed } \\
\text { relative to years before and after PHV } \\
\text { showed a general superiority of boys } \\
\text { compared to girls in all variables. }\end{array}$ \\
\hline
\end{tabular}




\begin{tabular}{|c|c|c|c|c|}
\hline Matsudo (22) & $\begin{array}{l}-5200 \\
- \text { Ages } \\
\text { between } \\
7 \text { and } 18 \\
\text { years. }\end{array}$ & $\begin{array}{l}\text { - Cross- } \\
\text { sectional }\end{array}$ & $\begin{array}{l}\text { - Physical fitness in developing } \\
\text { countries. } \\
\text { - Set of tests selected according } \\
\text { to criteria established by the } \\
\text { author. } \\
\text { - Motor } \\
\text { - Cardiorespiratory endurance } \\
\text { - Strength } \\
\text { - Inferior } \\
\text { - Speed } \\
\text { - Agility } \\
\text { - Somatic } \\
\text { - Weight } \\
\text { - Height } \\
\text { - Skinfolds } \\
\text { - Diameters } \\
\text { - Circumferences } \\
\text { - Maturation } \\
\text { - Socio-economic }\end{array}$ & $\begin{array}{l}\text { - For the same socio-economic status } \\
\text { differences in physical fitness } \\
\text { characteristics were not seen. } \\
\text { - Poor social conditions seems to have a } \\
\text { strong impact in maturational (height) } \\
\text { and functional growth curves. } \\
\text { - The disadvantages presented in } \\
\text { metabolic and neuromotors profiles } \\
\text { disappear when the absolute values } \\
\text { were corrected by weight and height. } \\
\text { - The profile for maturation curves was } \\
\text { very identical in different Regions } \\
\text { inside of the same country and in } \\
\text { countries with the same or distinctly } \\
\text { socio-economic conditions. } \\
\text { - Undernourished children seem to } \\
\text { present a later maturation and } \\
\text { understand an effort in a more } \\
\text { intensive way than the better } \\
\text { nourished children. }\end{array}$ \\
\hline Guedes (14) & $\begin{array}{l}-4289 \\
\text { [2186 } \\
\text { boys and } \\
2103 \\
\text { girls] } \\
\text { - Ages } \\
\text { between } \\
7 \text { and } 17 \\
\text { years. }\end{array}$ & $\begin{array}{l}\text { - Cross- } \\
\text { sectional }\end{array}$ & $\begin{array}{l}\text { - Growth, body composition and } \\
\text { motor performance in children } \\
\text { and teenagers of the } \\
\text { Municipality of Londrina. } \\
\text { - Set of tests selected according } \\
\text { to criteria established by the } \\
\text { author. } \\
\text { - Motor } \\
\text { - Cardiorespiratory endurance } \\
\text { - Flexibility } \\
\text { - Strength } \\
\text { - Upper body (static and } \\
\text { dynamic) } \\
\text { - Abdominal } \\
\text { - Inferior } \\
\text { - Speed } \\
\text { - Somatic } \\
\text { - Weight - Skinfolds } \\
\text { - Height }\end{array}$ & $\begin{array}{l}\text { - The children and youth of the Municipality } \\
\text { of Londrina present lower values in height } \\
\text { and weight relative to the remaining } \\
\text { samples. An identical situation is } \\
\text { observed in the moto r tests, ma inly for } \\
\text { the girls. } \\
\text { - The profile presented by somatic and } \\
\text { motor variables express a similar } \\
\text { configuration to the remaining studies. } \\
\text { - Only } 15 \% \text { of the population of the } \\
\text { Municipality of Londrina managed to } \\
\text { obtain the minimum health in } \\
\text { accordance to criterion-referenced } \\
\text { analysis. } \\
\text { - About } 13 \text { - } 14 \% \text { of the teenagers of this } \\
\text { study present very high adiposity } \\
\text { levels. }\end{array}$ \\
\hline Madureira (20) & $\begin{array}{l}-654 \\
\text { Brazilian } \\
\text { [375 } \\
\text { boys and } \\
279 \text { girls] } \\
\text { - } 356 \\
\text { Portugue } \\
\text { se [209 }\end{array}$ & $\begin{array}{l}\text { - Cross- } \\
\text { sectional }\end{array}$ & $\begin{array}{l}\text { - Anthropometrical, } \\
\text { maturational, physical fitness } \\
\text { and lifestyle and habitual } \\
\text { physical activity study on } \\
\text { Brazilian and Portuguese } \\
\text { students ages between } ? \text { and } \\
16 \text { of both sexes. } \\
\text { - Set of tests selected according }\end{array}$ & $\begin{array}{l}\text { - The menarche age was similar in both } \\
\text { groups but lower than in other } \\
\text { countries. } \\
\text { - In males, no significant statistic } \\
\text { differences occurred in pubic hair and } \\
\text { secondary sex characteristics. } \\
\text { - The body mass (weight) and the levels } \\
\text { of subcutaneous adiposity are similar }\end{array}$ \\
\hline
\end{tabular}




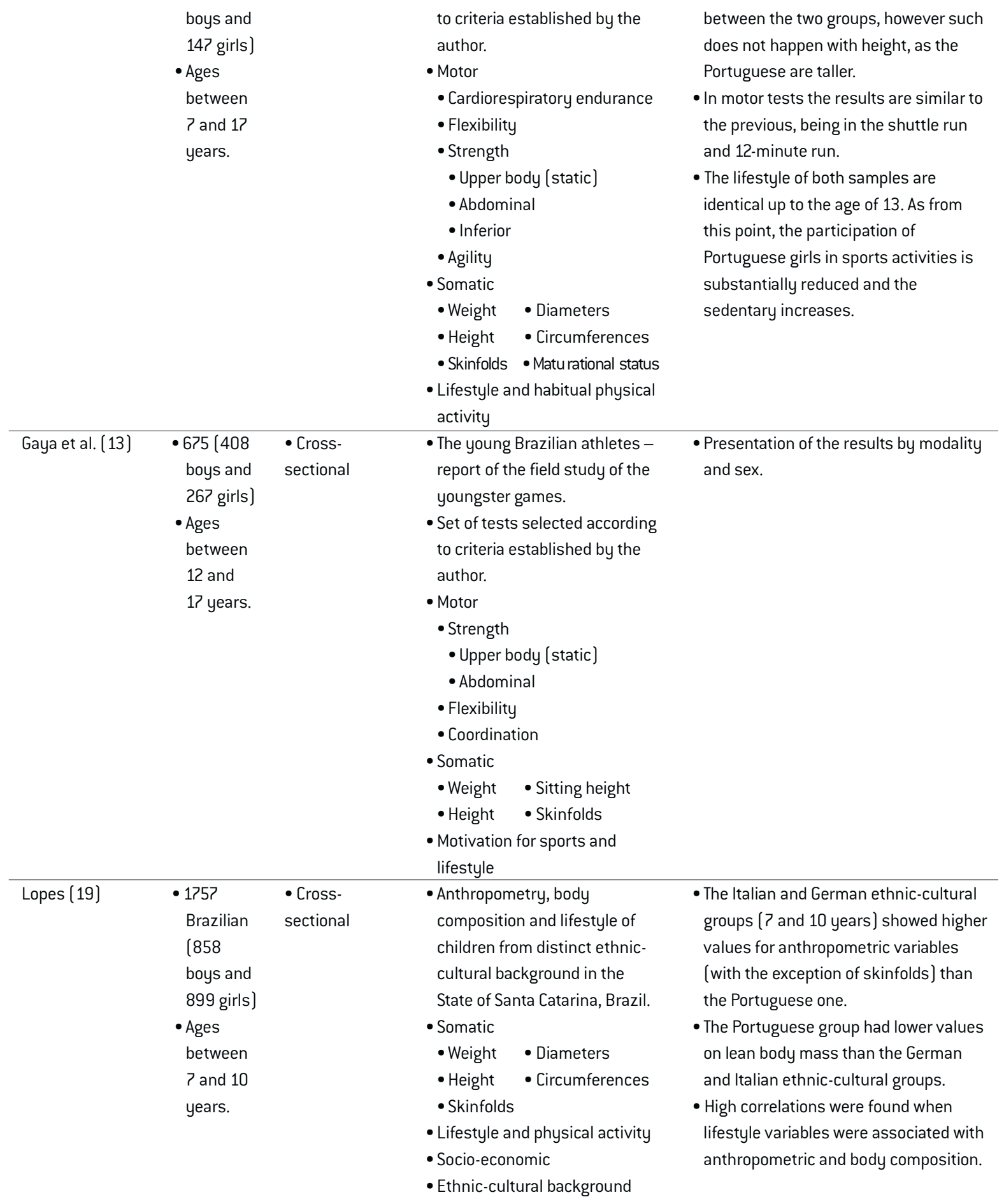


Table 3. Studies made in the Community of Portuguese Speaking Countries: Brazil and Cabo Verde Republic.

\begin{tabular}{|c|c|c|c|}
\hline Authors/Country & Subjects & Design & Title, test programs and components \\
\hline $\begin{array}{l}\text { Prista et al (28) } \\
\text { (Mozambique) }\end{array}$ & $\begin{array}{l}\text { - } 593 \text { ( } 277 \\
\text { boys and } \\
316 \text { girls) } \\
\text { - Ages } \\
\text { between } 8 \\
\text { and } 15 \\
\text { years. }\end{array}$ & $\begin{array}{l}\text { - Cross- } \\
\text { sectional }\end{array}$ & $\begin{array}{l}\text { - Relationship between physical } \\
\text { activity, socio-economic, and physical } \\
\text { fitness of 8-15-year-old youth from } \\
\text { Mozambique. } \\
\text { - AAHPERD (3); Eurofit (1) } \\
\text { - Motor } \\
\text { - Cardiorespiratory endurance } \\
\text { - Flexibility } \\
\text { - Strength } \\
\text { - Upper body (static) } \\
\text { - Abdominal } \\
\text { - Agility } \\
\text { - Somatic } \\
\text { - Weight } \\
\text { - Height } \\
\text { - Skinfolds } \\
\text { - Maturational status } \\
\text { - Physical activity } \\
\text { - Socio-economic } \\
\text { - Phusingoicalnarameters }\end{array}$ \\
\hline
\end{tabular}

Main results

- In the distance run tests and flexibility the Mozambique population presents higher results than the remaining studies.

- At the level of upper body and abdominal strength, the results presented by the population from Mozambique are inferior to those of developed countries.

- At anthropometric level, the Mozambique population presents itself in stature lower values than the international standards, reflecting a probable maturation delay.

- The profile of the habitual physical activity seems to be positively influenced by a specific sociocultural reality and is characterised by a volume and frequency slightly superior to that of populations of industrialized countries. The activities identified are of a spontaneous type and are connected to survival and leisure games.

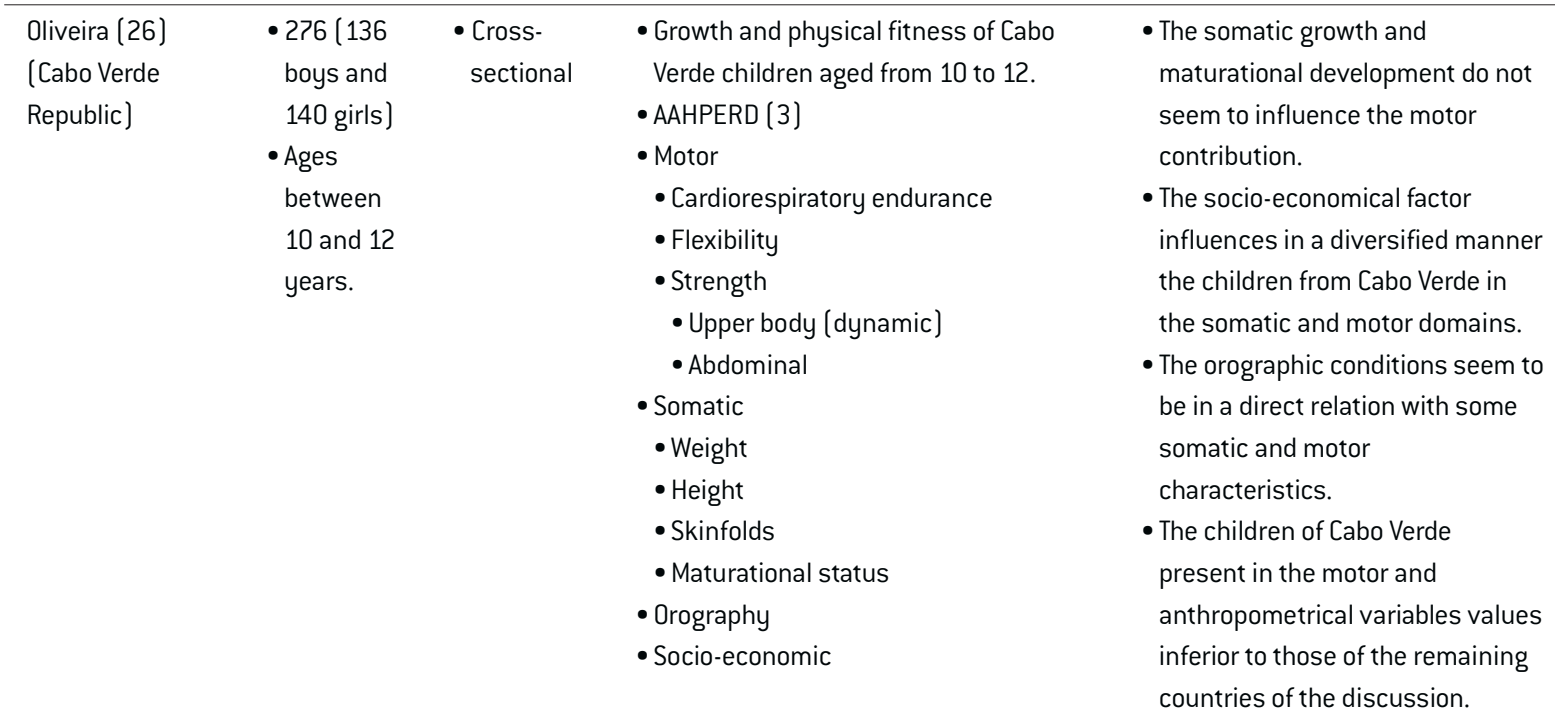


The studies of Sobral $(31 ; 32)$, Sobral and Marques (33), Duarte (8), Matsudo (22), Guedes (14), Prista et al. (28), Oliveira (26), Madureira (20) and Gaya et al. (13) relate the maturational status to morphology. For the calculation of the fat mass and fat-free mass, the relative amount of fat in the body (\% fat) sum of skinfolds, body mass index (BMI) and somatotype are the indicators used.

In general, EUROFIT (1988), and AAHPERD (3; 4) test batteries have been used in several growth studies. In Portugal, the FACDEX battery (33) was developed. The studies of Sobral $(31 ; 32)$, Duarte (8), Matsudo (22), Guedes (14), Sá (29), Madureira (20) and Gaya et al. (13), present a set of tests selected according to criteria established by the authors. The abdominal strength is the health-related fitness component included in almost all the studies. Few exceptions can be observed in studies made in Brazil by Duarte (8), Matsudo (22) and Lopes (19). Cardio-respiratory endurance was evaluated in thirteen studies and flexibility in eleven. Body composition is also considered in the studies of Sobral $(31 ; 36)$, Nahas et al. (23), Sobral and Marques (33), Duarte (8), Matsudo (22), Guedes (14), Prista et al. (28), Oliveira (26), Freitas et al. (10), Madureira (20) and Gaya et al. (13). For performance-related fitness, upper body strength (static and/or dynamic) was evaluated in nearly all the studies. Also explosive strength and velocity/agility, were investigated in twelve and thirteen studies, respectively. Balance is only evaluated in the study of Freitas et al. (10) and coordination, in the studies of Sobral and Marques (33), Freitas et al. (10) and Gaya et al. (13).

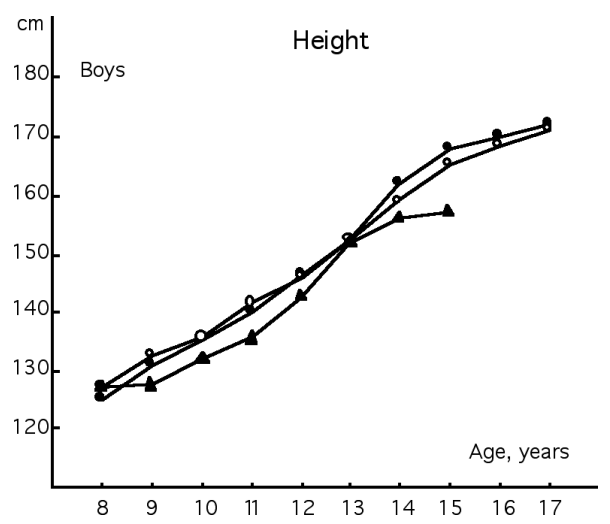

For somatic and fitness characteristics reference values are constructed and age and sex specific means and standard deviation are provided for each of the somatic dimensions and tests. Guedes (14) also considers the fitness levels with regard to criteria proposed in the North American battery AAHPERD Physical Best (4) for the sit and reach, sit ups and 9and 12- minute run/walk tests.

The evaluation of the lifestyle and physical activity is object of study in Sobral and Marques (33), Madureira (20), Freitas et al. (10), Gaya et al. (13), Prista et al. (28) and Lopes (19). In all these studies physical activity was assessed by means of selfreported questionnaires. In the studies of Madureira (20), Gaya et al. (13) and Lopes (19) the questionnaire used was the one developed by Sobral and Marques (33) to evaluate the lifestyle of children and youth in the Region of Oporto during childhood and adolescence (EVIA). Prista et al. (28) developed a 'weekly description' model adopted for Mozambique population and lifestyle whereas Freitas et al. (10) used the Baecke questionnaire (5). When comparing some somatic characteristics in CPLP studies, the average height values of Brazilian (14) and Portuguese (10) samples are very similar (Fig. 1). For boys from 8 to 11 years of age the Brazilians are slightly taller than those from Portugal but this situation changes from 11 years onwards when the Portuguese show higher averages. For girls, a similar trend is observed but the Portuguese sample only surpasses the Brazilian at the age of 16 and 17 . With regard to Mozambique, boys are clearly smaller in comparison to Portuguese and Brazilian samples. For girls, the differences in height are small.

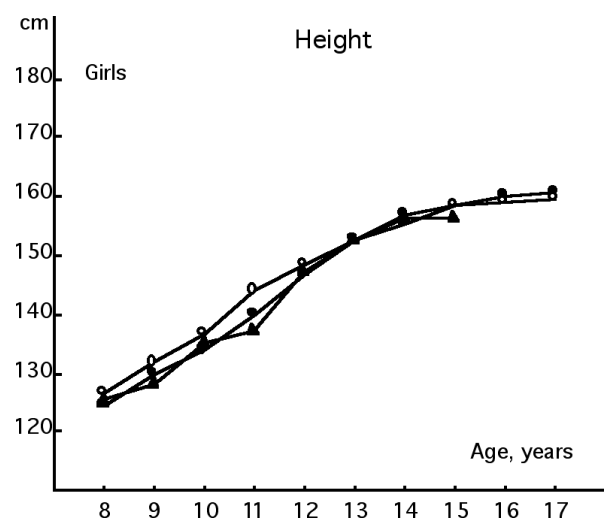

Figure 1 Height of Brazilian ( $\bigcirc$ ), Portuguese ( $\bullet$ ) and Mozambique ( $\mathbf{\Delta}$ ) boys and girls. Data are from Guedes (14), Freitas et al. (10) and Prista et al. (28), respectively. 
For body mass, similar differences as to height were found in both sexes (Fig. 2). Portuguese and Brazilian boys present nearly coincident values from 8 to 11 but from this age onwards the Portuguese sample is greater in terms of weight than the Brazilian. Brazilian girls show higher body mass averages from 8 to 12 but the values are more or less the same from the ages of 13 through to 15 .

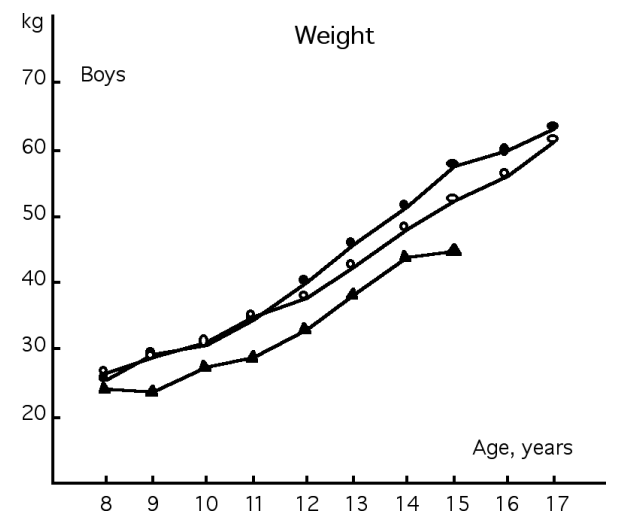

Figure 2 Weight of Brazilian ( 0 ], Portuguese ( $)$ ] and Mozambique ( $\mathbf{\Delta}$ ] boys and girls. Data are from Guedes (14), Freitas et al. (10) and Prista et al. (28), respectively.

The average levels of subcutaneous fat obtained by the sum of triceps and subscapular skinfolds show that Portuguese and Brazilian children and youth, of both sexes, present higher adiposity values than Cabo Verde (26) and Mozambique (28) samples (Fig. 3 ). Between Portuguese and Brazilian boys the first ones present higher subcutaneous fat levels at all age groups but the results are very close at the age of 10, 11 and 17. In contrast, the Brazilian girls have higher

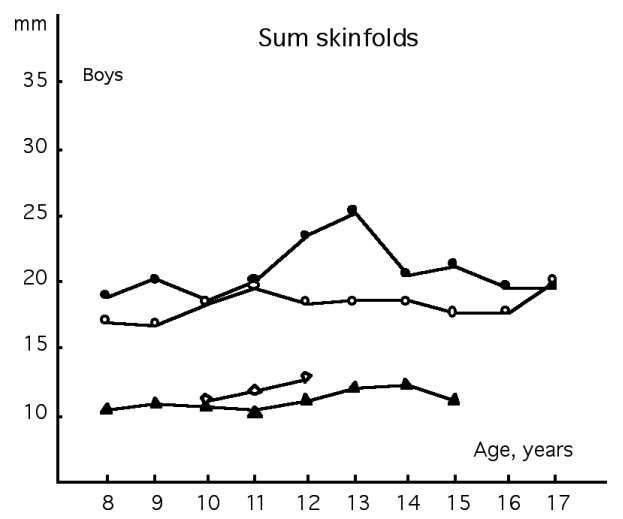

Once more, the Portuguese sample presents higher body mass averages at 16 and 17 . When Mozambique, Brazilian and Portuguese samples are compared the same tendency as to height can be observed: Mozambique boys and girls have lower body mass than Brazilian and Portuguese youngsters but the differences in girls are smaller than in boys.

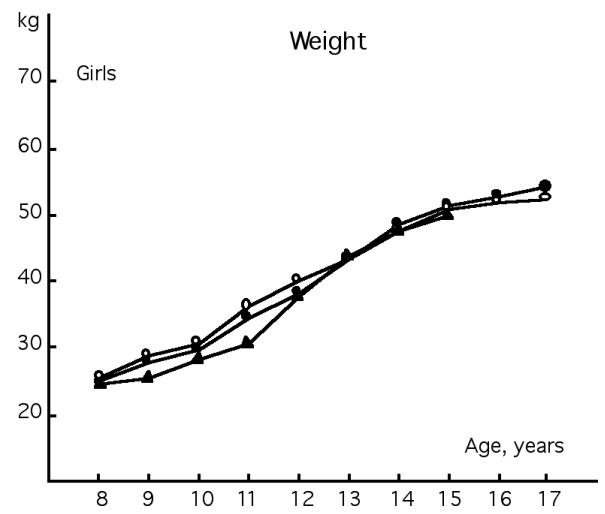

adiposity than Portuguese girls at all age groups with exception of 11 years of age where the opposite was found. The Cabo Verde boys have higher subcutaneous fat than those of Mozambique at the age of 10, 11 and 12. For girls, no general trend can be seen between the two samples with Cabo Verde girls showing higher adiposity than those of Mozambique at 10 and 11 and lower at the age of 12 .

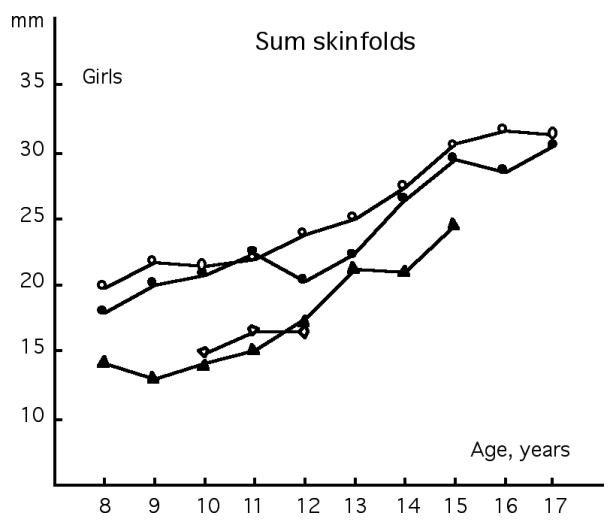

Figure 3 Sum of skinfolds (triceps and subscapular] of Brazilian ( $\bigcirc$ ), Cabo Verde ( $\diamond)$, Portuguese ( $\bullet$ ) and Mozambique ( $\mathbf{\Delta}$ ) boys and girls. Data are from Guedes [14], Oliveira [26], Freitas et al. (10) and Prista et al. (28), respectively. 
The performance on sit and reach test of the Mozambique and Cabo Verde samples of both sexes is higher than those of Portuguese and Brazilian

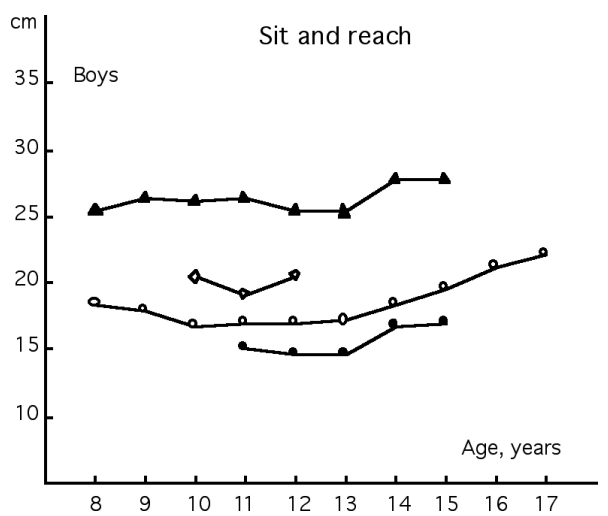

children and youth (Fig. 4). The best results are obtained by Mozambique boys and girls, followed by Cabo Verde, Brazilian and Portuguese samples.

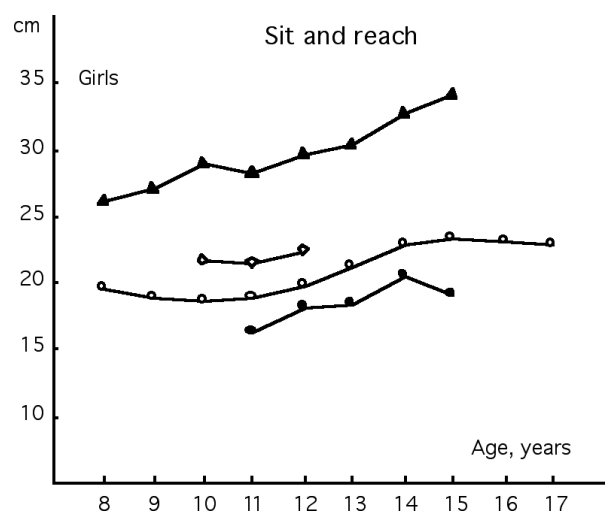

Figure 4 Performance on sit and reach in Brazilian [ 0 ], Cabo Verde $(\diamond)$, Portuguese ( $\bullet$ ) and Mozambique ( $\Delta$ ) boys and girls. Data are from Guedes (14), Oliveira [26], Freitas et al. (11) and Prista et al. (28), respectively.

For sit ups Portuguese and Brazilian children and youth of both sexes present higher performances than those of Mozambique as was observed for stature and body mass (Fig. 5). The growth curves for trunk strength of boys and girls from Brazil and
Portugal show approximately the same pattern from 11 to 15 years old, however, the Brazilian sample performs slightly better than the Portuguese one. For girls at the age of 12 and 13 the opposite can be found with better results in the Portuguese sample.
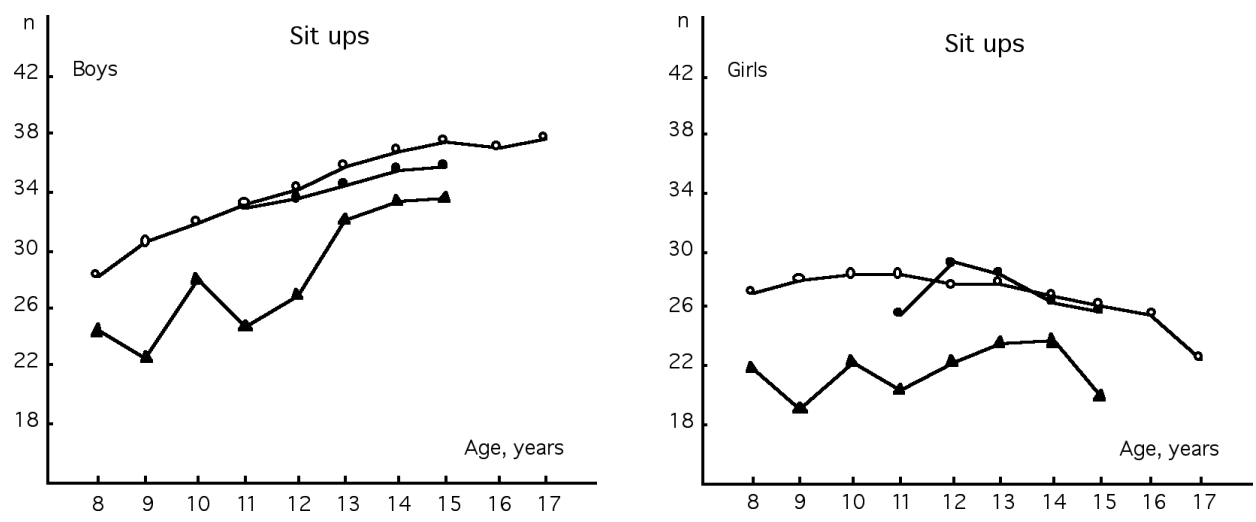

Figure 5 Performance on sit ups in Brazilian ( 0 ], Portuguese ( $\bullet$ ) and Mozambique ( $\mathbf{\Delta}$ ) boys and girls. Data are from Guedes (14), Freitas et al. (11) and Prista et al. (28), respectively. 
Finally, the Portuguese boys and girls perform better than the Brazilian sample at all age groups on 12minute run/walk test (Fig. 6). An exception can be

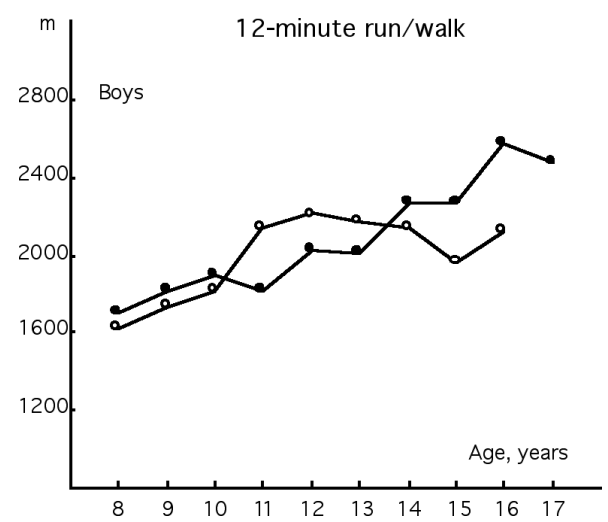

observed for boys at the age of 11,12 and 13 where the Brazilian sample showed higher performances compared to the Portuguese.

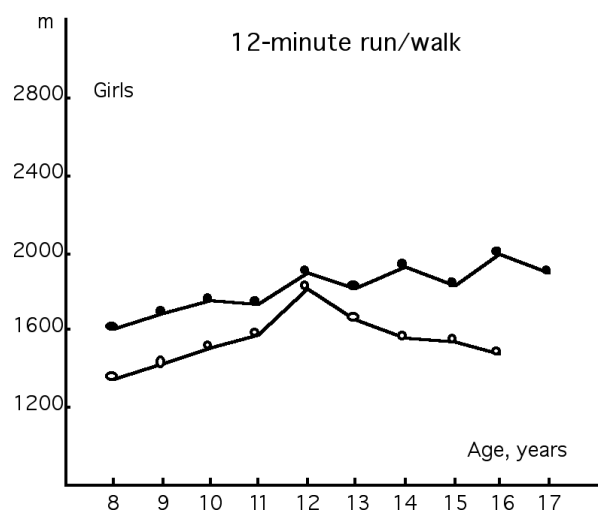

Figure 6 Performance on 12-minute run/walk in Brazilian ( 0 ) and Portuguese ( $\bullet$ ] boys and girls. Data are from Madureira (20) and Freitas et al. (11), respectively.

\section{DISCUSSION}

The non-existence of the normal revision process in some publications can lead to incorrect suppositions and some weakness in the discussion of the results. Also, the non-access to raw data did not allow us to do a more powerful statistic analyses. In present review, the studies made in the CPLP were compared to multidisciplinary studies of growth and fitness in Belgian $(27 ; 30)$ and Netherlands $(16 ; 17)$. Out of the 17 CPLP studies only four, i.e. Brito (7), Nunes et al. (25), Nascimento (24) and Freitas et al. (11), focus uniquely on physical fitness, this is, a unique agglomerate of motor components. The remaining 13 studies are multidisciplinary, encompassing motor, somatic and physical activity characteristics as well as physiological, coordination, postural and socio-economic parameters.

The studies of Simons et al. (30) and Kemper (16; 17) still include more characteristics. In the study on Flemish girls apart from the somatic, motor and social dimensions, the pulmonary function and cardio-respiratory parameters are also studied. In the Dutch study (16) four groups of measurements can be identified: (a) biological measurements, anthro- pometry, menarche, skeletal age, physiological characteristics and motor performance tests-MOPER Fitness Test; (b) psycho-social methods (personality, school attitude and sociometric status); (c) eating and smoking habits; and (d) physical activity. In the follow-up of the Amsterdam Growth Study (17) new items were included, namely, bone mineral density and dietary calcium intake, analyses of blood, urine and saliva, now comprising five domains: (a) biological measurements of body size, build, and composition; (b) motor performance and physiological measurement; (c) psychological measurements and personality; (d) lifestyle measurements concerning dietary habits, physical activity, psycho-social behaviour, and stress; and (e) health measurements, concerning both physical and mental aspects.

This demonstrates that the CPLP studies were less multidisciplinary, that the focus was less on healthrelated fitness items and that there is a need to follow the literature in the field closely so that the recent techniques can be incorporated.

In each country there is a concern with constructing its own standards in growth, maturation and physical fitness. In the CPLP the results of each 
variable/test are presented by age and sex through the mean and standard deviation, whereas the studies of Ostyn et al. (27), Kemper (16; 17) and Simons et al. (30) use percentile scales.

Out of the seventeen studies conducted in the CPLP fourteen have a cross-sectional design and only three a longitudinal or mixed-longitudinal designs. Taking into account that individual growth characteristics can only be investigated by means of longitudinal and mixed-longitudinal designs it becomes necessary to conduct longitudinal and mixed-longitudinal studies in the CPLP. Such studies would permit to study growth patterns and tracking as is done in the studies of Beunen et al. (6) and Kemper (17) for somatic and motor characteristics.

In the CPLP only one study is conducted to investigate the adolescent growth spurt in the different somatic and performance characteristics. This weakness seems to be associated with financial and technical aspects. Longitudinal studies require long-term financial obligations (due to their high cost) and the necessity of a permanent attendance of the test team. Furthermore, there is also the risk of dropouts - essential condition for the success of this type of investigation.

With regard to data input and quality control, the studies of Ostyn et al. (27) and Simons et al. (30) constitute good models. In epidemiological studies, special attention should be given to the training of the test team and errors that may occur in the data collecting (misreading an instrument, in transcribing data into forms, in coding answers to questions, or in punching data to tape or disk). In an attempt to evaluate these errors and, if possible to limit them, Ostyn et al. (27) describe the training of test teams under the supervision of the experienced instructors. In the study of Simons et al. (30) a team was trained during a 45 day period, in which each test leader was involved in a pilot study during which 450 individuals of both sexes and different age groups were measured and tested.

An important aspect of the measurement/evaluation of the anthropometric and motor variables consists in the determination of the errors of measurement and the presentation of the reliability of the tests and measurements. Both Ostyn et al. (27) and Simons et al. (30) conducted test-retest reliability studies and reliability studies before the main project started. Subsequently they developed in-field methods to evaluate the in field reliability and measurement error.

Also during data entry quality control was carried out. All individual data were entered twice into a computer file and under program control the two data sets were compared, errors deleted and verified with the original data sheets. The following step led to the elimination of the outliers whenever the value registered was very different from the value estimated. In the study of Simons et al. (30), whenever this difference was superior to 2.58 times the standard error of measurement the outlier was verified with the original data sheet. If the outlier was correct as documented by other characteristics it was accepted, if no clear evidence was presented it was deleted. In studies conducted in the CPLP, references to the quality of the evaluation results and the methodological rigour of the investigation are presented by Duarte (8), Guedes (14), Prista et al. (28), Oliveira (26), Madureira (20), Nascimento (24) and Freitas et al. $(10 ; 11)$.

The reliability and reproducibility of anthropometric and physical fitness variables were evaluated by Duarte (8) in a group of 5 girls and 7 boys using a two day test-retest procedure. The reliability of the data was very high, with correlation ( $r$ ) values ranging from 0.85 to 1.0 . The reproducibility evaluated by the student t-test showed no significant mean differences between days for any of the variables, suggesting very good reproducibility.

In a pilot study Guedes (14) investigated the reproducibility of motor and somatic measurements. For body dimensions the correlation varied between 0.97 and 0.99 and technical error of measurement was low indicating a good agreement between the two evaluations. For motor tests, correlation coefficients vary between 0.76 and 0.93 indicating sufficient test-retest reliability. Lowest reliability was observed in children aged less than 12 years in the 9/12minute run/walk and standing long jump. In this study, one of the purposes was also to determine the overall reproducibility level of the set of motor tests. Canonical correlation coefficients for the two sets of tests varied between 0.48 and 0.99 for the six subgroups considered and values of total redundancy 
(Rd) between 0.87 and 0.88 . Since the estimate of total redundancy reflects the concordance level in the variation between the two sets of tests, about 87 to $88 \%$ of the variation found in the motor test results was common to both sets of tests.

A similar work was conducted in the Autonomous Region of Madeira by Freitas et al. (11; 9). In first place, we intended to know the reliability of the tests (absolute and relative reliability), of the different items of the FACDEX battery (33), of the students who participated in the 'Physical Fitness of the School Population of Autonomous Region of Madeira'. The second step was the evaluation of the global reliability of the battery. Regarding the first aspect, the execution of a retest to a sub-sample of 134 students allowed the extraction of intraclass correlation coefficients (relative reliability) and the standard error of measurement (absolute reliability), both by age group. Values of $\mathrm{R}$ between 0.78 and 0.99 , show, clearly, the high test-retest reliability. Also the standard error of measurement (SEM) was low for motor tests. Noteworthy is that, as observed by Guedes (14), the highest standard error of measurement occurred in the 12-minute run/walk and in standing long jump. However, 'Mixed Anova' did not show any significant pattern of learning or testing effect over age groups. With respect to the overall reliability of the FACDEX battery, the results of the canonical correlation analysis indicate redundancy levels (Rd1) between 0.66 and 0.80 , in the first evaluation, and $\mathrm{Rd} 2$ between 0.71 and 0.82 in the second, which shows that the battery as a whole is reliable and stable across groups.

Also in this context, Prista et al. (28) validated a questionnaire to estimate the habitual physical activity of Mozambique children and youth. A group of children was observed during 24 hours by 12 observers. The activities observed led to the construction of a set of questions to be included into two types of questionnaires: the ' 24 hour description' and the 'weekly description' models.

The validity of the two models was determined by a pilot study. A group of 16 students was observed for a period of 24 hours. Each individual was followed by two distinct observers who independently registered the activities carried on. The following day, each student was interrogated by an interviewer with the ' 24 hour description model' and, fifteen days later, the same individuals were interviewed by the 'weekly description model'. The comparison of the activity values observed and registered in interview revealed intraclass correlation coefficient between 0.10 and 0.80 for the ' 24 hour description model', which indicates that the individuals manifested little ability in the self-report of the time involved in daily physical activity. For the 'weekly description model' the observation and interview results were compared by ANOVA (one way) based on the Activity Coefficient manifested in the questionnaire by two distinct groups: active (EM equal or superior to P50) and non-active (EM inferior to P50). The active group shows higher values than the non-active, although without a statistical significance. The analysis of the results, at an individual level, reveals that $83 \%$ of the individuals were correctly classified into the active group indicating that the self-reported weekly description is associated with the more objective observation. Subsequently the reliability of the weekly self-reported questionnaire was studied using a test-retest design.

Reliability coefficients for the different items varied between 0.30 and 0.80 with an average value of $\mathrm{R}=0.71$ )

In the studies of Oliveira (26), Madureira (20) and Nascimento (24), the analysis of the data was preceded by a study of the normality of the distributions of the characteristics under investigation and the eventual presence of outliers was verified. Madureira (20) and Nascimento (24) present reliability values, obtained by the test-retest procedure an intraclass correlation coefficient, equal or superior to 0.72 $[\mathrm{R}>0.95$ - Madureira (20); $0.72<\mathrm{R}<0.99$ Nascimento (24)]. There are no references to the preparation of the test team or execution of pilot studies.

It should be mentioned that in the studies made in the CPLP the interrelation between growth, maturation, physical activity and performance were only partly investigated. Matsudo (22) studied the relationship between growth, maturation, physical fitness and socio-economic status. Duarte (8) analysed the relationship between growth, maturation and physical fitness, while Lopes (19) investigated the connection between growth and physical activity. 
Prista et al. (28) related the concepts of growth, maturation, physical fitness and physical activity, and Oliveira (26) studied the relationship between growth, maturation, physical fitness and socio-economic status.

In an attempt to situate the CPLP studies in another context we plotted some somatic characteristics and motor tests against Belgian data. For height, boys and girls from Brazil and Mozambique are slightly shorter than Belgians (Fig. 7). This difference is more notable for Mozambique sample of both sexes while Brazilian girls are closer to the height averages presented by Flemish girls at 8, 9, 10 and 11 years old. Similar analysis was made by Guedes (14) and
Prista et al. (28) when comparing the Brazilian and Mozambique data with North-American reference values (15). For Brazilian boys differences of about 2 to 5 centimetres less than North Americans can be observed from 10 years onwards whereas, in girls, this difference is about 2 centimetres. The average height of boys from Mozambique comes close to the P5 of the NCHS norms and for girls within the P5 and P50 channel. In both studies these differences are explained through the interacting effects between environmental conditions and genetics potential, i.e. the environmental conditions are insufficient to obtain optimal growth as determined by genetic potential.
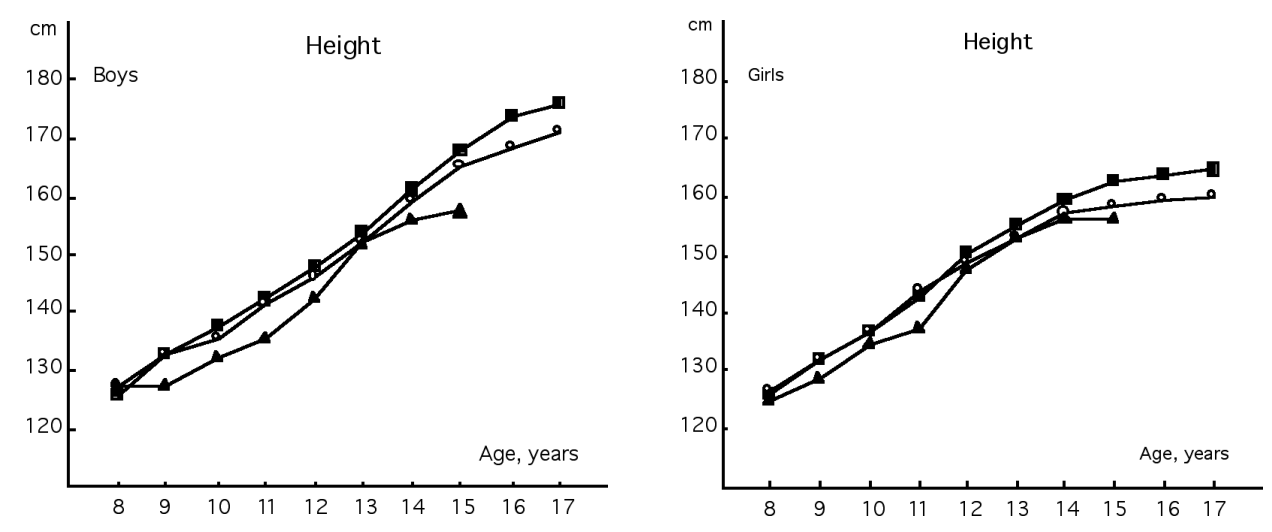

Figure 7 Height of Brazilian ( $\mathrm{O}$ ), Belgian ( $\mathbf{\square}$ ) and Mozambique ( $\mathbf{\Delta}$ ) boys and girls. Data are from Guedes (14), Lefevre et al. (18) and Prista et al. (28), respectively.

For body mass, children and youngsters from Mozambique are lighter than Belgians at all age groups and in both sexes (Fig. 8). Similar weights are presented by Portuguese girls from 8 to 13 years old but the difference between the two samples is strongly marked from 14 to 17 years where the Portuguese sample showed lower body mass averages. For boys, data are nearly identical from 8 to 11 years and from 16 to 17 years old. From 12 to 15 years the Portuguese boys are heavier than the Belgians. The lighter weight expressed by Mozambique sample, in comparison to the Portuguese and Belgian samples may be explained by a lower stature. Prista et al. (28), although in another context, compared the average values of his sample with the averages proposed by Frisancho (1990) for relative weight of North American black people. The values came close to the P50. With regard to the Portuguese sample the intermediate body mass levels and lower stature relative to the Belgian boys and girls can be associated to the fat accumulation. 

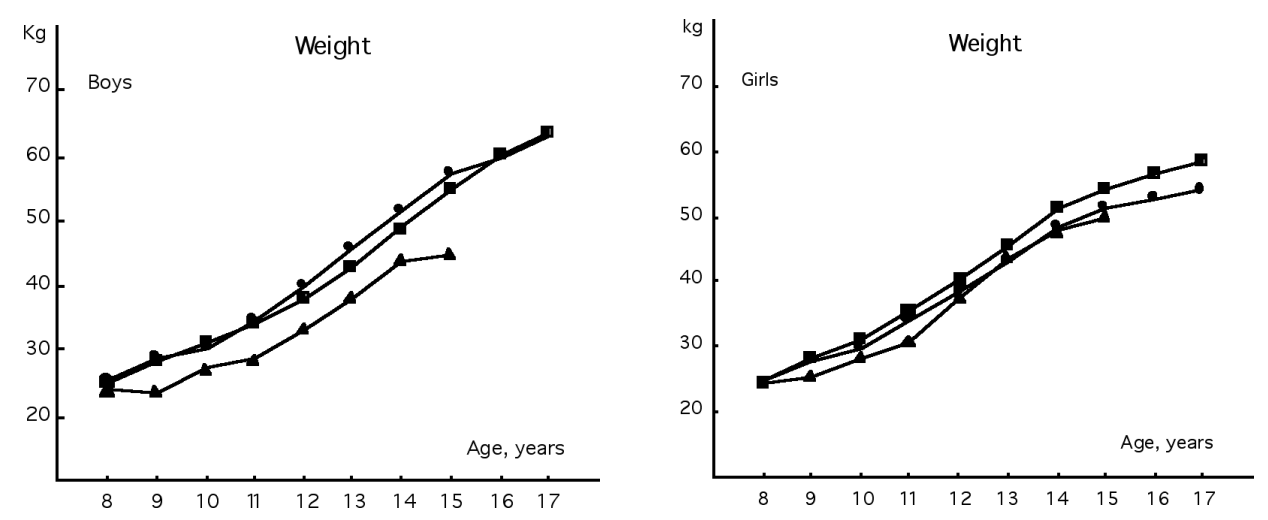

Figure 8 Weight of Portuguese ( $\bullet$ ), Belgian ( $\mathbf{\square}$ ) and Mozambique ( $\mathbf{\Delta}$ ) boys and girls. Data are from Freitas et al. (10), Lefevre et al. (18) and Prista et al. (28), respectively.

The average levels of subcutaneous fat (sum of triceps and subscapular skinfolds) of Portuguese, Belgian and Mozambique samples are presented in Fig. 9. Once again, the Mozambique sample of both sexes has lower skinfold values than Belgian and Portuguese boys and girls. For Portuguese boys, slightly higher subcutaneous fat levels are presented relatively to the Flemish boys. For girls, the skinfold values are very close to each other and no consistent pattern of differences can be found between the two samples. These data strengthen the previous suggestion that the intermediate weight levels and lower stature presented by Portuguese sample could be associated to the fat accumulation. For children and youth from Mozambique the lower body mass can be explained not only by a shorter stature but also by lower subcutaneous fat levels.
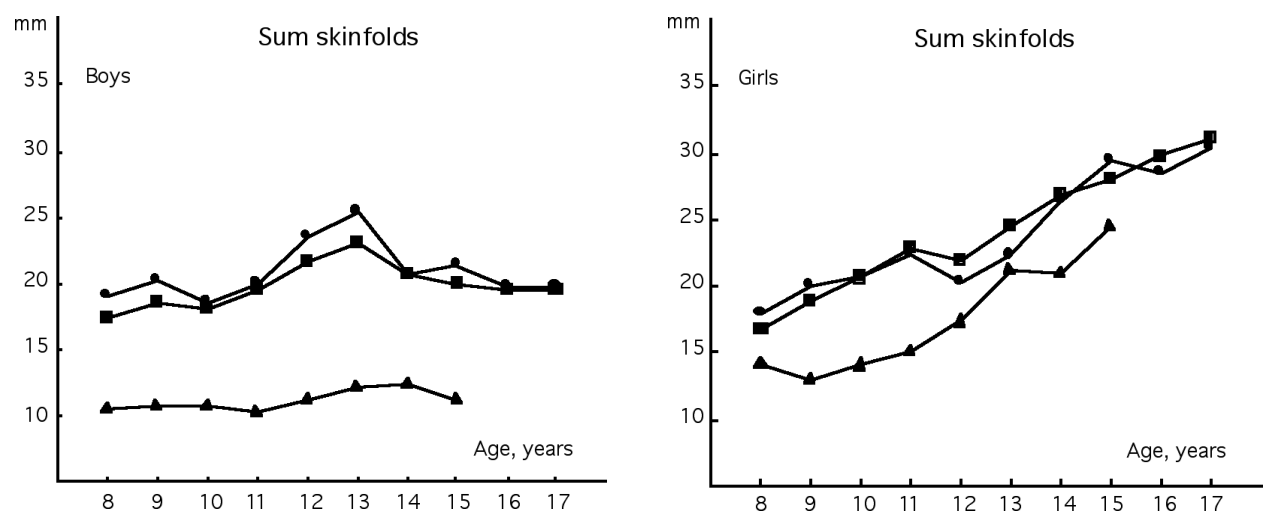

Figure 9 Sum of skinfolds (triceps and subscapular) of Portuguese ( $\bullet$ ], Belgian [ $\mathbf{0}$ ) and Mozambique ( $\mathbf{\Lambda}$ ) boys and girls. Data are from Freitas et al. (10), Lefevre et al. (18) and Prista et al. [28), respectively. 
For motor dimensions, and with regard to the sit and reach test, Mozambique boys and girls obtain better results than Belgians at all age levels (Fig. 10). For Brazilian boys the results are very close to the Belgian sample but girls present lower performances at all age groups. Similar findings were

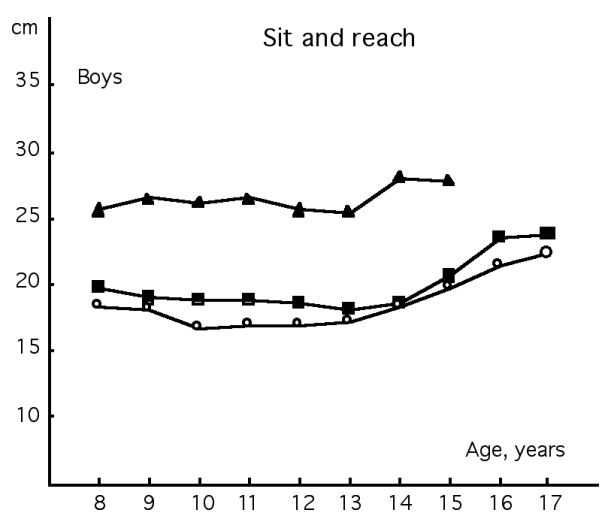

observed by Prista et al. (28) and Guedes (14) when Mozambique and Brazil data were plotted against North-American norms (4). The clear advantage of Mozambique sample was justified by these authors through a different type of physical activity carried out by children and youth from Mozambique.

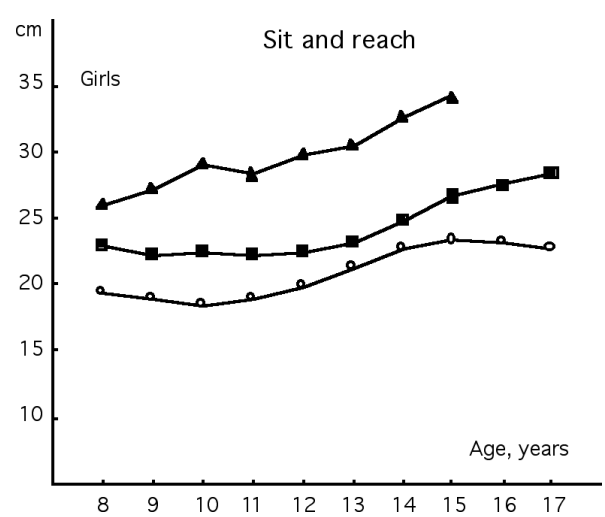

Figure 10 Performance on sit and reach in Brazilian [ O], Belgian ( $\mathbf{0}$ ) and Mozambique ( $\mathbf{\Delta}$ ) boys and girls. Data are from Guedes [14), Lefevre et al. (18) and Prista et al. (28), respectively.

\section{CONCLUSIONS}

The studies made in the CPLP reflect the concern of each country/territory in characterising and describing their population/group reporting specific reference data for growth, maturation, physical fitness and physical activity.

Among the different countries/territories the highest number of studies reviewed is conducted in Portugal and Brazil. On the seventeen studies twelve included somatic and fitness characteristics. For motor fitness, the measurement of the abdominal and explosive strength is common in nearly all the studies. The physical activity is object of study in the investigations made by Sobral and Marques (33), Madureira (20), Freitas et al. (10), Gaya et al. (13), Prista et al. (28) and Lopes (19). In this domain, all studies used self-reported questionnaire.

Almost all the studies conducted in the CPLP present a cross-sectional design. Few exceptions are the preliminary presentation of the mixed-longitudinal study in progress in the Autonomous Region of Madeira - Portugal (10) and the longitudinal studies made by Nahas et al. (23) and Duarte (8) in Brazil. The studies of Duarte (8), Guedes (14), Prista et al. (28) and Freitas et al. $(10 ; 9)$ present a similar methodology to those developed in Belgium by Ostyn et al. (27) and Simons et al. (30). However, the non-existence of strategies to include procedures to control data quality during data collection and data entry reflects some of the methodological weaknesses in these studies.

The multidisciplinary factor of the CPLP studies is operationalised by the inclusion of physical fitness dimensions, somatic characteristics, lifestyle and physical activity, coordination, posture, socio-economic status, and some physiological parameters. The associations between the dimensions are only partially studied $(8 ; 22 ; 28 ; 19 ; 26)$.

In CPLP context, data from Portugal (10) and Brazil (14) present nearly identical average height and 
body mass values, those from Mozambique (28) are shorter and lighter. Portuguese and Brazilian samples present higher subcutaneous fat levels (sum of triceps and subscapular skinfolds) than Cabo Verde (26) and Mozambique. For motor dimensions, boys and girls from Mozambique perform better than Brazilian, Cabo Verde and Portuguese samples on sit and reach. The opposite holds true for sit ups where children and youth from Brazil and Portugal (11) show better results than Mozambique sample. On 12-minute run/walk, Portuguese sample performs better than Brazilian one.

In European context, boys and girls from Brazil (14) and Mozambique (28) are slightly shorter than Belgians (18). Similar body mass can be observed in Portuguese and Belgian samples. Children and youth from Mozambique are lighter and have lower subcutaneous fat levels (sum of triceps and subscapular skinfolds) than Portuguese and Belgians. For Portuguese boys, slightly higher subcutaneous fat levels are presented relatively to the Flemish boys whereas, in girls, skinfolds values are very close to each other. For sit and reach test, Mozambique boys and girls perform better than Belgians. For Brazilian boys the results are very close to the Belgian sample but girls present lower performances at all age groups. Consequently future projects in the area of growth, maturation, fitness and physical activity should consider: (1) longitudinal or mixed-longitudinal design; (2) multidisciplinary test teams; (3) well defined methodologies in training of test team - courses of anthropometric and evaluation of physical tests; identification and familiarisation with the evaluation instruments - codes, control and verification; practice; pilot study; (4) rigorous quality control during data collection and data entry; and (5) inclusion of parameters related to health.

\section{ADDRESS}

\section{Duarte Luís de Freitas}

Universidade da Madeira

Campus Universitário da Penteada - Secção

Autónoma de Educação Física e Desporto

9000.390 Funchal

Portugal

dfreitas@uma.pt 


\section{REFERENCES}

1. Adam C, Klissouras V, Ravassolo M et al. (1988). Eurofit, handbook for the Eurofit test of physical fitness. Rome: Council of Europe. Committee for the Development of Sport.

2. American Alliance for Health, Physical Education, Recreation (1965). Youth fitness test manual. Washington.

3. American Alliance for Health, Physical Education, Recreation, and Dance (1980). Health related physical fitness manual. Washington.

4. American Alliance for Health, Physical Education, Recreation, and Dance (1988). Physical best. Washington.

5. Baecke JA, Burema J, Frijters JE (1982). A short questionnaire for the measurement of habitual physical activity in epidemiological studies. A. J. Clin. Nutrit. 36: 936-942.

6. Beunen GP, Malina RM, Van't Hof MA, Simons J, Ostyn M, Renson R, Van Gerven D (1988). Adolescent growth and motor performance - a longitudinal study of Belgian boys. HKP Sport Science Monograph Series. Champaign, IL: Human Kinetics Books.

7. Brito AP (1972). Sondagens sobre a condição (performance) da população escolar feminina portuguesa de onze, treze e quinze anos. Ed. e Movimento 16: 21-25.

8. Duarte MF (1993). Longitudinal study of pubertal peak height velocity and related morphological and functional components in Brazilian children. Thesis submitted in partial fulfilment of the requirements for the degree of Doctor of Philosophy in Kinesiology in the Graduate College of the University of Illinois at Urbana-Champaign.*

9. Freitas DL, Maia JA, Marques AT (1998). Sexual dimorphism in physical fitness - a multivariate analysis of structural differences. In: Proceedings of the International Council for Physical Activity and Fitness Research - ICPAFR Symposium 96. Physical activity and health - physiological, behavioural and epidemiological aspects. Treviso, 187-195.

10. Freitas DL, Maia JA, Marques AT, Beunen GP, Claessens AL, Lefevre JA, Crespo T, Rodrigues A (1997a). Madeira growth study: model, preparation and first results. Eur. J. Phys. Educ. Abstract, 1(2):105-106.

11. Freitas DL, Marques AT, Maia JA (1997). Aptidão física da população escolar da Região Autónoma da Madeira. Funchal: Universidade da Madeira.

12. Frisancho AR (1990). Anthropometric standards for the assessment of growth and nutritional status. Michigan: University of Michigan Press.

13. Gaya A, Cardoso M, Torres L, Sequeira O (1997). Os jovens atletas Brasileiros - relatório do estudo de campo dos Jogos da Juventude. Ministério Extraordinário dos Esportes/INDESP. Rio Grande do Sul: Universidade Federal.

14. Guedes DP (1994). Crescimento, composição corporal e desempenho motor em crianças e adolescentes do Município de Londrina. Dissertação apresentada às provas de doutoramento. Brasil: Escola de Educação Física-USP**

15. Hamill PV, Drizd TA, Johnson CL, Reed RB, Roche AF, Moore WM (1979). Physical growth: National Center for Health Statistics percentiles. A. J. Clin. Nutrit., 32: 607-629.

16. Kemper HC (ed.) (1985). Growth, health and fitness of teenagers - longitudinal research in international perspective. Med. Sport Sci Vol. 20. New York: Karger.

17. Kemper HC (ed.) (1995). The Amsterdam growth study - a longitudinal analysis of health, fitness, and lifestyle. HK Sport Science Monograph Series Vol. 6. Champaign: Human Kinetics Books.

18. Lefevre JA, Beunen GP, Borms J, Vrijens J (1998). Sex differences in physical fitness in Flemish youth. In: Parizkova
J, Hills AP (eds). Physical fitness and nutrition during growth Vol. 43. Med Sport Sci. Basel: Karger, 54-67.

19. Lopes AS (1999). Antropometria, composição corporal e estilo de vida de crianças com diferentes características étnico-culturais no estado de Santa Catarina, Brasil. Tese apresentada ao Programa de Pós-graduação em Ciência do Movimento Humano da Universidade Federal de Santa Maria (RS), como requisito parcial à obtenção do título de Doutor em Educação Física. *

20. Madureira AS (1996). Estudo antropométrico, maturacional, da aptidão física e do estilo de vida e actividade física habitual de escolares Brasileiros e Portugueses dos 7 aos 16 anos de ambos os sexos. Dissertação apresentada às provas de doutoramento. Porto: FCDEF-UP**

21. Marques AT, Gomes PB, Oliveira J, Costa A, Graça A, Maia JA (1992). Aptidão Física. In: Sobral F, Marques AT (eds). Desporto Escolar - FACDEX, Desenvolvimento Somato-Motor e Factores de Excelência Desportiva na População Portuguesa. Vol. 2. Relatório Parcelar Área do Grande Porto.. Lisboa: Ministério da Educação. Gabinente Coordenador do Desporto Escolar, 21-44.

22. Matsudo VK (1993). Aptidão física nos países em desenvolvimento. Espaço 1:2:23-32.

23. Nahas MV, Petroski EL, Jesus JF, Silva OJ (1992). Crescimento e aptidão física relacionada à saúde em escolares de 7 a 10 anos - um estudo longitudinal. Revista Brasileira de Ciências do Desporto 14(1):7-16.

24. Nascimento MF (1996). Aptidão física da população escolar do Distrito de Aveiro - estudo em crianças e jovens dos 11 aos 14 anos de idade. Dissertação apresentada às provas de mestrado. Porto: FCDEF-UP*

25. Nunes L, Soares M, Lourenço J (1981). Caracterização do adolescente escolar - avaliação da condição física. In: Comunicações das I Jornadas de Informação Científico-Desportiva. Lisboa: IND, 39-64.

26. Oliveira EC (1999). O crescimento e a aptidão física das crianças Cabo-Verdianas dos 10 aos 12 anos. Cabo Verde: Instituto de Promoção Cultural.

27. Ostyn M, Simons J, Beunen GP, Renson R, Van Gerven D (1980). Somatic and Motor Development of Belgian Secondary School Boys.- Norms and Standards. Leuven: Leuven University Press.

28. Prista A, Marques AT, Maia JA (1997). Relationship between physical activity, socioeconomic status, and physical fitness of 8-15-year-old youth from Mozambique. American Journal of Human Biology 9:449-457.

29. Sá JE (1995). Aptidão física e desporto escolar. Estudo em jovens dos dois sexos dos 13 aos 15 anos de idade da Região Autónoma dos Açores. Dissertação apresentada às provas de mestrado. Porto: FCDEF-UP*

30. Simons J, Beunen GP, Renson R, Claessens AL, Vanreusel B, Lefevre JA (1990). Growth and fitness of flemish girls - the Leuven growth study. HKP Sport Science Monograph, Series 3. Champaign: Human Kinetics Publishers, Inc.

31. Sobral F (1986). Estatística e normas antropométricas e de valor físico. SREC-DREFD. Lisboa: RAA/ISEF-UTL.

32. Sobral F (1989). Estado de crescimento e aptidão física na população escolar dos Açores. SREC-DREFD. Lisboa: RAA/ISEFUTL.

33. Sobral F, Marques AT (eds) (1992). FACDEX, desenvolvimento somato-motor e factores de excelência desportiva na população Portuguesa - relatório parcelar área do Grande Porto, Vol. 2. Lisboa: Ministério da Educação. Gabinete Coordenador do Desporto Escolar.

* Unpublished data 